\title{
Functional small airways defence in symptomless cigarette smokers
}

\author{
JE AGNEW, MT LOPEZ-VIDRIERO, D PAVIA, SW CLARKE \\ From the Departments of Medical Physics and Thoracic Medicine, Royal Free Hospital and School of Medicine, \\ London
}

\begin{abstract}
Smoking induced changes in the secretory cells of bronchiolar epithelium by facilitating secretion of cross linked glycoprotein mucus may influence the efficiency of mucus-cilia coupling. The functional impact on mucociliary transport in small (peripheral) airways has been studied by comparing data on aerosol deposition and clearance from symptomless cigarette smokers (30 tests, 18 subjects) with data from age matched non-smokers (30 tests, 19 subjects). Gamma camera images, assessed in terms of a penetration index comparing peripheral with inner zone deposition, indicated closely similar initial deposition in the two groups. Alveolar deposition, however, assessed in terms of particle retention at 24 hours, was significantly $(p<0.01)$ less in the smokers. Given the similarity of initial deposition, this implies that an increased proportion of small conducting airways are protected by mucociliary defence in the smokers' lungs. Clearance from conducting airways of the peripheral zone in tests with relatively high peripheral deposition (14 tests on smokers, and 12 on non-smokers) nevertheless proceeded at the same rate in smokers as in non-smokers.
\end{abstract}

Mucociliary transport is generally taken to be the basic mechanism that removes mucus and matter entrapped in it from the ciliated conducting airways. The effects of cigarette smoking on the cells and glands from which airways mucus originates cause qualitative and quantitative changes in the load placed on the mucociliary "escalator." These changes may in turn alter the efficiency of the mucus-cilia coupling, which transmits the driving force of that escalator.

The earliest pathophysiological effects attributable to smoking occur in the distal small airways. ${ }^{1}$ Despite this, no satisfactory evidence has been available on the effectiveness of mucociliary defence in the peripheral conducting airways of smokers' lungs. We now present data indicating a difference between smokers and non-smokers in the amount of mucus removed from peripheral airways but similarity in the rate at which mucus is removed from these airways.

Address for reprint requests: Dr JE Agnew, Department of Medical Physics, Royal Free Hospital, London NW3 2QG.

Accepted 10 January 1986

\section{Methods}

Results from 30 tests of radioaerosol deposition and clearance carried out in symptomless cigarette smokers under the age of 50 were compared with those from 30 tests in healthy non-smokers of similar age. The tests concerned were drawn from several studies of mucociliary clearance carried out in our departments over the past five years. All subjects gave informed, written consent and the radioaerosol procedure has been approved by the ethical practices committee of the Royal Free Hospital. Pulmonary function was assessed by dry bellows spirometer (Vitalograph) 10-20 minutes before each radioaerosol inhalation and was compared with published predicted values. ${ }^{2}$ Each subject was asked to record any coughs (including throat clearings) during the first six hours after radioaerosol inhalation; most of the subjects were members of the hospital staff performing ordinary duties between times of attendance at the laboratory and so we recognise that some of their records of cough frequency may be incomplete.

The radioaerosol inhalation procedure ${ }^{3}$ comprised eight breaths of $450 \mathrm{ml}$ volume taken from approximately functional residual capacity, each followed by a three second breath hold to encourage deposition by sedimentation in the more distal airways. A 


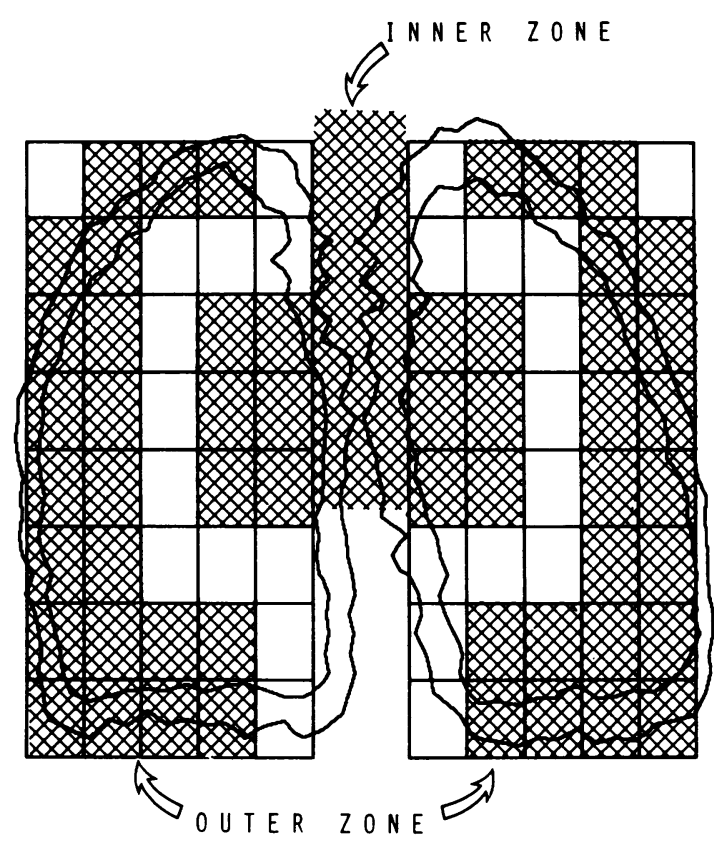

Fig 1 Inner and outer zones used in defining penetration index. The outer zone was also used for assessing peripheral airways clearance. The irregular lines are contours of the distribution of inhaled krypton $81 \mathrm{~m}(15 \%$ and $30 \%$ contours relative to the hottest cell in the ${ }^{81 \mathrm{~m}} \mathrm{Kr}$ image matrix).

pneumotachograph system was used to record the duration of each breath and the volume inhaled was controlled by a solenoid valve activated from a Krogh spirometer; dividing volume by duration gave a value for mean inspiratory flow rate. The technetium $99 \mathrm{~m}$ $\left({ }^{99 \mathrm{~m}} \mathrm{Tc}\right)$ radioaerosol particles were $5 \mu \mathrm{m}$ in diameter and initial activity in the lungs was about $1 \mathrm{MBq}$ $(27 \mu \mathrm{Ci})$. A twin counter system was used to record
${ }^{99 \mathrm{~m}} \mathrm{Tc}$ retention in the lungs shortly after inhalation, at hourly intervals for six hours and then finally at 24 hours. The 24 hour reading (corrected for radioactive decay and expressed as a percentage of the initial reading) was taken as alveolar deposition (AD). Because the mucociliary phase of particle clearance, in asymptomatic smokers as in non-smokers, is virtually complete within 24 hours, ${ }^{45}$ this $A D$ value defines the percentage of lung aerosol deposition not on the mucociliary escalator (deposition on the mucociliary escalator $=100 \%-\mathrm{AD}$ ). Clearance from the alveolar zone occurs at a very much slower rate. $^{6}$

A gamma camera image was recorded 10-15 minutes after inhalation in all subjects and also (in 23 tests on smokers and 21 on non-smokers) about one, two, four, and six hours after inhalation. A krypton $81 \mathrm{~m}\left({ }^{81 \mathrm{~m}} \mathrm{Kr}\right)$ ventilation image was used in defining inner and outer lung zones (fig 1 ) so that the penetration index (PI) could be calculated-that is, the ratio of outer to inner zone radioactivity for ${ }^{99 \mathrm{~m}} \mathrm{Tc}$ divided by the corresponding value for ${ }^{81 \mathrm{~m}} \mathrm{Kr} .{ }^{5}$

Tracheobronchial retention (based on readings corrected for decay from the twin counters) was calculated by subtracting $\mathrm{AD}$ from each reading and then expressing it as a percentage of the initial reading (corrected for alveolar deposition). Similar calculations for the peripheral zone (based on the sequential gamma camera images) required estimation of alveolar deposition in the peripheral zone. This was achieved by combining the twin counter result for total alveolar deposition with an estimate of alveolar deposition distribution derived from the ${ }^{81 \mathrm{~m}} \mathrm{Kr}$ image. The basis for this procedure and tests on its validity have been published elsewhere. ${ }^{7}$ To ensure adequate counting statistics within the peripheral zone, retention in the peripheral zone was analysed only for tests in which PI $\geqslant 0.6$ (the value of 0.6

Table 1 Lung function, aerosol inhalation and deposition data (means with standard deviations* in parentheses)

\begin{tabular}{|c|c|c|c|c|}
\hline & \multicolumn{2}{|l|}{ All tests } & \multicolumn{2}{|c|}{$\begin{array}{l}\text { Tests in which peripheral zone airways } \\
\text { clearance was analysed }\end{array}$} \\
\hline & Non-smokers & Symptomless smokers & Non-smokers & Symptomless smokers \\
\hline $\begin{array}{l}\text { No of subjects } \\
\text { No of tests } \\
\text { Age (y) } \\
\text { Cigarette consumption (pack y) } \\
\text { FEV }(1) \\
\text { FEV }(\% \text { predicted) } \\
\left.\text { MMF (1 s }{ }^{-1}\right) \\
\text { MMF (\% predicted) } \\
\text { Radioaerosol inhalation }\end{array}$ & $\begin{array}{c}19(9 \mathrm{~F}, 10 \mathrm{M}) \\
30 \\
29(10) \\
-\quad \\
4.1(0 \cdot 7) \\
113(16) \\
4.6(0.8) \\
101(21)\end{array}$ & $\begin{array}{c}18(5 \mathrm{~F}, 13 \mathrm{M}) \\
30 \\
32(9) \\
15(14) \\
3.8(0.7) \\
102(12) \\
4.1(0.9) \\
93(18)\end{array}$ & $\begin{array}{c}10(3 \mathrm{~F}, 7 \mathrm{M}) \\
12 \\
31(12) \\
-\quad \\
4.0(0.8) \\
107(12) \\
4.0(0.6) \\
90(18)\end{array}$ & $\begin{array}{c}10(2 \mathrm{~F}, 8 \mathrm{M}) \\
14 \\
31(8) \\
14(15) \\
3.8(0.8) \\
102(11) \\
4.2(0.9) \\
93(15)\end{array}$ \\
\hline $\begin{array}{l}\text { flow rate }\left(\mathrm{min}^{-1}\right) \\
\text { Penetration index } \\
\% \text { alveolar deposition }\end{array}$ & $\begin{array}{l}32(13) \\
0.63(0.14) \\
55(13)\end{array}$ & $\begin{array}{l}35(15) \\
0.63(0.17) \\
44(14) \dagger\end{array}$ & $\begin{array}{l}26(14) \\
0.72(0.09) \\
62(10)\end{array}$ & $\begin{array}{l}33(12) \\
0.74(0.10) \\
50(13) \ddagger\end{array}$ \\
\hline
\end{tabular}

* Mean and SD values calculated for total number of tests analysed in each case.

tSignificant difference between smokers and non-smokers $(p<0.01)$.

+Significant difference between smokers and non-smokers $(\mathrm{p}<0.02)$.

MMF-maximal mid expiratory flow. 


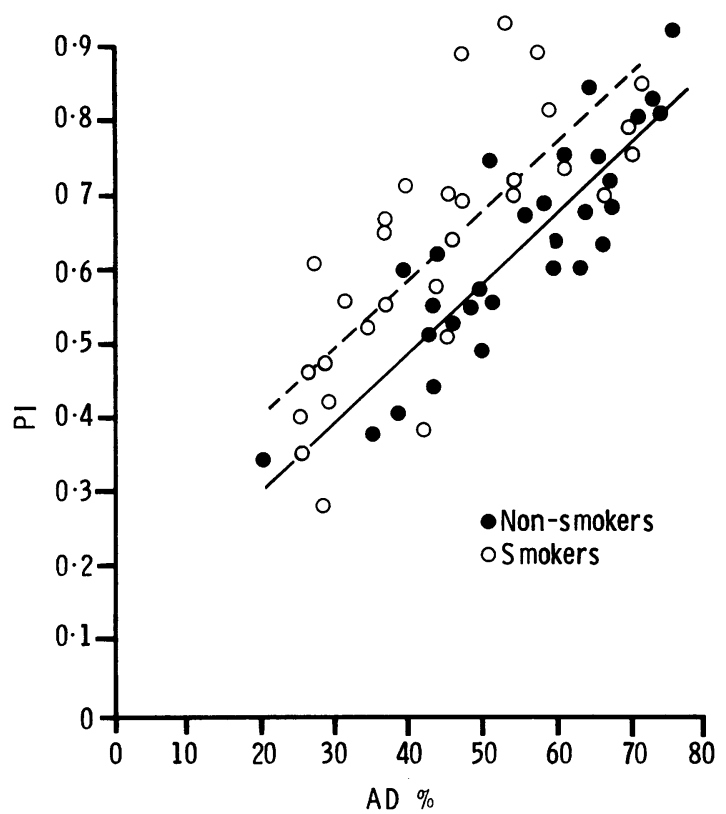

Fig 2 Relationship between penetration index (PI) and alveolar deposition $(A D)$ in non-smokers $(r=0.88, p<$ $0.001)$ and in symptomless smokers $(r=0.76, p<0.001)$.

being an arbitrary but reasonable choice).

Statistical comparisons between groups were performed with Student's $t$ test, and analysis of covariance ${ }^{8}$ was used to test the difference in position between regression lines of similar slope.

\section{Results}

The groups of smokers and non-smokers were quite closely matched for age and lung function (table 1). The mean PI was closely similar in the two groups but AD was significantly $(p<0.01)$ less in smokers than in non-smokers; the relationship between PI and AD is illustrated in figure 2. The two regression lines shown are similar in slope (non-smokers, 0.0094; smokers, 0.0090 ) but differ significantly in position $(t=3.7, \mathrm{p}<0.001)$, the mean PI corresponding to any given $\mathrm{AD}$ being about 0.1 higher in smokers than in non-smokers. The implication is that for any particular division of aerosol particles between deposition on the mucociliary escalator $(100 \%-A D)$ and deposition not on the mucociliary escalator (AD), the mean particle deposition site - as seen by the gamma camera-tends to be more peripheral in smokers than in non-smokers. Any given value of percentage particle deposition on the mucociliary escalator is associated with a higher ratio of outer to inner zone deposition in smokers than in non-smokers. At the same time, the similarity of mean PI values in the smoker and non-smoker groups (table 1) cannot be taken to mean that initial particle deposition is similarly distributed between proximal and distal sites on the mucociliary escalator in the two groups.

Mean tracheobronchial clearance in all 30 tests on smokers (fig 3) was significantly slower than in nonsmokers ( $\mathrm{p}<0.01$ for retention at 6 hours). Mean cough frequency reported in smokers was less than three coughs per six hours (range 0-12), while most of the non-smokers reported no coughs at all (the highest number recorded was four). Even if we allow for some under-recording of coughs, it therefore seems unlikely that cough contributed substantially to the clearance patterns of figure 3 .

$\%$ retention

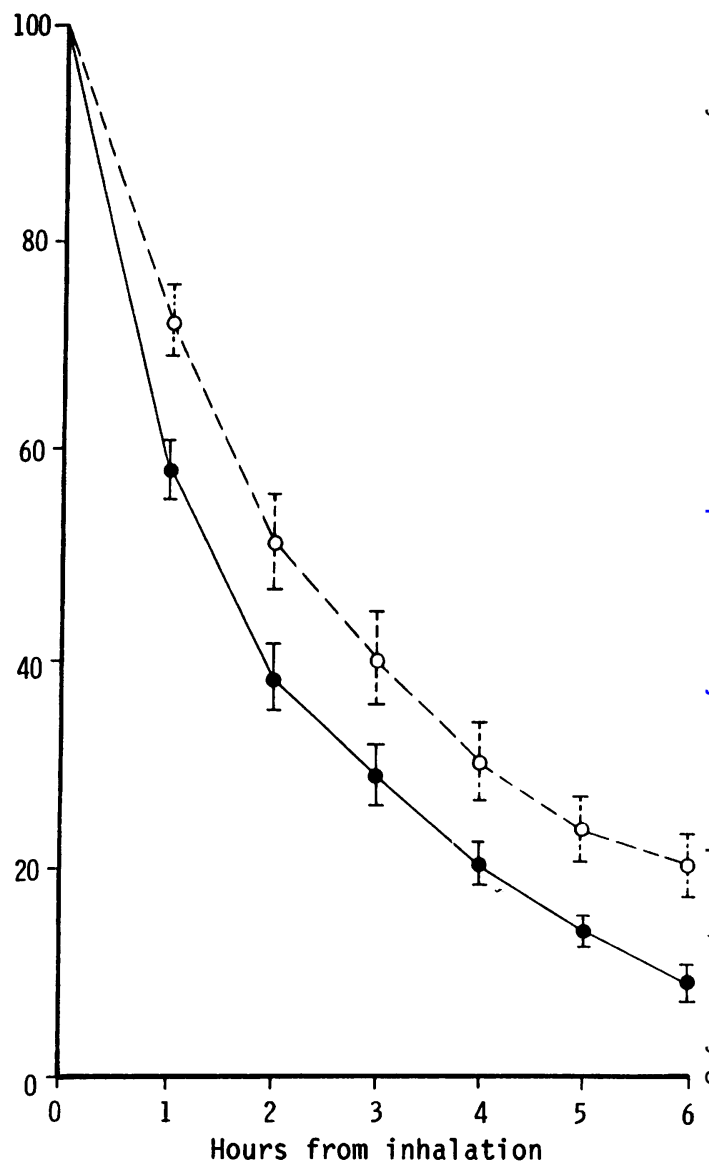

Fig 3 Mean tracheobronchial retention (standard errors indicated by bars) in symptomless smokers $(\bigcirc-\bigcirc)$ and in non-smokers (- Assessed by the t test, the difference between groups is significant at each hour: $p<$ 0.05 at 2, 3, 4, and 5 hours and $p<0.01$ at 1 and 6 hours after inhalation. 
Table 2 Tracheobronchial retention (means with standard deviations in parentheses) in tests for which peripheral zone clearance was analysed (figures in square brackets are corresponding values for all tests)

\begin{tabular}{lccc}
\hline $\begin{array}{l}\text { Tracheobronchial } \\
\text { retention }(\%) \text { at }\end{array}$ & Non-smokers & Symptomless smokers & $\begin{array}{l}\text { Significance of difference } \\
\text { between smokers and } \\
\text { non-smokers }(p)\end{array}$ \\
\hline 2 hours & $36(14)[38(17)]$ & $56(24)[51(25)]$ & $<0.02[<0.05]$ \\
6 hours & $9(6)[9(8)]$ & $19(16)[20(17)]$ & $<0.05[<0.01]$ \\
\hline
\end{tabular}

A comparison of clearance that can be specifically related to peripheral defence was obtained from the sequential gamma camera images. Restriction of this analysis to the results of tests with high peripheral deposition $(P I \geqslant 0.6)$ yielded data from 14 tests

\section{$\%$ retention}

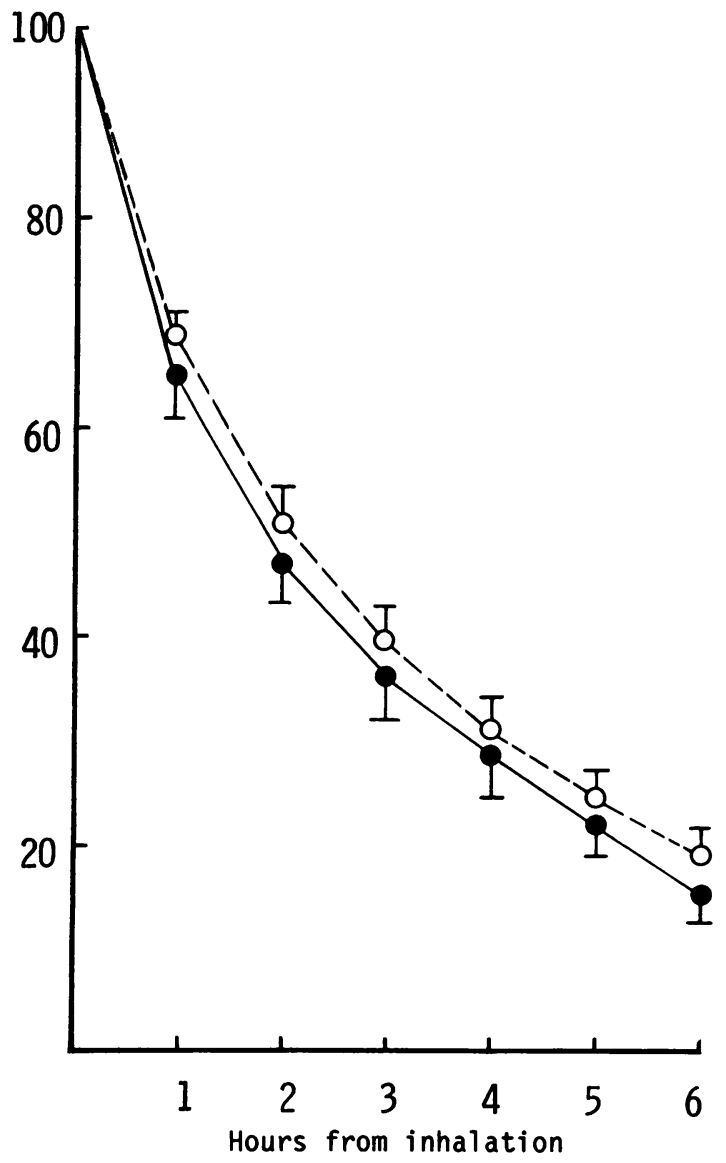

Fig 4 Mean peripheral airways retention in symptomless smokers ( $\bigcirc-\bigcirc)$ and in non-smokers ( ensure adequate peripheral airways deposition this analysis was restricted to tests with relatively high total peripheral deposition (penetration index $\geqslant 0.60$ ). There is no significant difference between the two curves at any time interval. on smokers and 12 on non-smokers (table 1), whose tracheobronchial clearance from the lung as a whole differed little from that for all subjects (table 2) and whose peripheral airways retention is shown in figure 4. No significant difference in retention was detectable between smokers and non-smokers at any hourly interval after inhalation. By six hours after inhalation some $18 \%$ of particles available for clearance in the smokers remained in the peripheral zone, as against a retention of $14.5 \%$ in non-smokers.

\section{Discussion}

Mucus transport rates in the bronchioles of the normal lung are much slower than in the bronchi ${ }^{910}$ - a distinction attributable to differing sources of mucus supply (table 3 ) and perhaps to differing morphology and activity of the ciliated cells. Cross-linked polymers, such as the glycoproteins derived from mucus cells and submucosal glands, are required for effective coupling with cilia. ${ }^{11-14}$ But within the normal bronchiole there is no abundant source of any such polymers; the Clara cells appear to secrete mainly proteins and lipids with little or no cross linking. ${ }^{15}{ }^{16}$ It has therefore been suggested that mucociliary transport per se may not function effectively throughout normal bronchioles. ${ }^{17}$ There remains the possibility that some transport may be achieved by "milking" and "squeezing" effects over the respiratory cycle or by a directional transport phenomenon ("stop and go"), which can be demonstrated by the alternate compression and expansion of a monomolecular film. ${ }^{18}$

Bronchiolar epithelium from smokers, on the other hand, readily secretes glycoproteins. ${ }^{19}$ The smokers' bronchioles have much more abundant mucus cells (very few are found in non-smokers) and fewer Clara cells. ${ }^{20-23}$ The logical inference must be that a greater extent of bronchiolar protection by

Table 3 Major sources for the macromolecular constituents of airways mucus in normal non-smokers

\begin{tabular}{ll}
\hline Bronchi with cartilage & Bronchioles \\
\hline $\begin{array}{l}\text { Surface epithelium } \\
\text { mucus cells }\end{array}$ & $\begin{array}{l}\text { Surface epithelium } \\
\text { Clara cells }\end{array}$ \\
$\begin{array}{l}\text { Submucosal glands } \\
\text { Tissue fluid exudate }\end{array}$ & Tissue fluid exudate \\
Mucus from the bronchioles & Liquid from the alveolar zone \\
\hline
\end{tabular}


mucociliary transport is available to the smoker. The relationship we report between penetration index and alveolar deposition (fig 2) supports this proposition. In essence, we find the same initial gamma camera images in smokers as in non-smokers, with the same mean PI in the two groups (table 1); but our 24 hour clearance data show that more particles are cleared from the lung by mucociliary action in the smokers (mean AD 44\%) than in the non-smokers (mean AD $55 \%$ ). An enhanced deposition in the peripheral conducting airways of the smokers could in theory result from changes in airway calibre. Under the inhalation conditions used, however, bronchiolar deposition results from a mixture of impaction and sedimentation, ${ }^{524}$ the former enhanced by constriction of the bronchioles and the latter by dilatation. Modelling studies suggest that large changes would be required for any appreciable effect: a $20 \%$ reduction of mean bronchiolar diameter is predicted to cause an increase of only a few percent in particle deposition in the bronchioles. ${ }^{25}$ Histopathological data (from subjects somewhat older than ours), however, suggest that the mean bronchiolar diameter differs little between smokers and non-smokers. ${ }^{21} 26$ Thus, as any direct mechanical effect on particle deposition seems unlikely, we argue that increased bronchiolar glycoprotein secretion in smokers really is translated into an enhanced mucociliary protection of the smokers' bronchioles-and that our data (fig 2) illustrate this functional, change.

By the same argument, the average distance for particle clearance from the initial deposition site to the trachea should be greater in smokers than in nonsmokers. This must contribute to the smokers' delayed tracheobronchial clearance, assessed in terms of clearance from the lung as a whole (fig 3 ). Our present data do not, however, rule out the possibility of a further contribution from delayed transit through the larger bronchi. ${ }^{27}$

When attention is focused on peripheral conducting airways (fig 4), a minimal difference in clearance is apparent between smokers and non-smokers. This implies a well functioning mucociliary defence system in the smokers' small airways.

Other aspects of altered bronchiolar mucus composition in smokers may, however, be detrimental. Cigarette smoking almost certainly affects all the mucus sources shown in table $3^{19-232829}$ and also the rates of transport of fluid and small solutes across airway and alveolar epithelium ${ }^{30}$; consequently it may give rise to significantly diminished bronchiolar surfactant concentrations. Surfactant helps to maintain bronchiolar stability ${ }^{31}$ and minimise the work of breathing, ${ }^{32}$ so lowered concentrations could in the long term contribute to impairment of lung function.

Experimental evidence attributes the characteristic early bronchiolar inflammation of smokers' lungs ${ }^{1}$ to the particulate phase of cigarette smoke. ${ }^{33}$ Our inert test particles cannot precisely mimic the deposition of smoke particulates-if only because of differences in size. Measured after dilution with clean air, the mean diameter of cigarette smoke particles ${ }^{34}$ comes to only about $0.5 \mu \mathrm{m}$ (one tenth of the size of our particles). In vivo, however, coagulation, hygroscopic growth, and behaviour as a "dense smoke aerosol" 35 all contribute to deposition and the effective size is uncertain. Nevertheless, total lung deposition of cigarette smoke under varying conditions ranges from $80 \%$ to $100 \%,{ }^{34}$ which is similar to that occurring with $5 \mu \mathrm{m}$ particles and far more than would be expected with $0.5 \mu \mathrm{m}$ particles. ${ }^{36}$ Bronchiolar deposition of our test particles may therefore roughly parallel that of smoke particles.

Previous assessments (in most instances testing clearance from the larger bronchi rather than from peripheral airways) have presented conflicting results concerning clearance rates in symptomless smokers. ${ }^{2737-40}$ Peripheral clearance can be satisfactorily measured only when an adequate proportion of the test aerosol is deposited peripherally. ${ }^{41}$ In the present study this was ensured by analysing peripheral clearance only for tests in which there was a relatively high penetration index. It is therefore of some interest that our results differ from those recently reported by Foster et al, ${ }^{40}$ who found significantly prolonged peripheral retention in six young smokers with moderately high peripheral deposition (mean AD 45\%); these smokers reported low cigarette consumption ( $<5$ pack years) and their aerosol deposition pattern was indistinguishable from that of age matched non-smokers. Our results may therefore represent a slightly later stage in the lung's response to smoking.

Our data on clearance emphasise the near normality of peripheral airways clearance rates in symptomless smokers with some 10-20 pack years of cigarette consumption. Our data on deposition (fig 2) are consistent with the proposition that the mucociliary escalator in such persons chronically has to carry a heavier load of mucus originating (in part) from peripheral secretion sites. It has been speculated that impaired mucociliary transport in "healthy" smokers may act as a pathogenetic factor in the development of airflow obstruction, ${ }^{3740}$ and clearance is generally accepted as being severely retarded in smokers who have developed chronic bronchitis. ${ }^{373942}$ Whether or not progressive changes in mucociliary transport have any pathogenetic role, they may well represent the breakdown of an overloaded clearance mechanism. This, rather than a slow rate of peripheral clearance per se, might play a part in some smokers' progression towards clinically 
evident airflow obstruction.

In summary, we conclude that increased glycoprotein mucus secretion in smokers may contribute to effective mucociliary defence of the symptomless smokers' bronchioles. The mucociliary escalator seems to extend more distally in the lungs of smokers than of non-smokers and to carry a heavier "load"-yet in symptomless smokers we find that it maintains a normal rate of peripheral airway clearance.

We thank Dr JRM Bateman, Dr PP Sutton, and Mr HS Williams for their help, advice, and encouragement.

\section{References}

1 Niewoehner DE, Kleinerman J, Rice DB. Pathologic changes in the peripheral airways of young cigarette smokers. N Engl J Med 1974;291:755-8.

2 Cotes JE. Lung function: assessment and application in medicine. 4th ed. Oxford: Blackwell Scientific Publications, 1979.

3 Pavia D, Bateman JRM, Sheahan NF, Clarke SW. Clearance of lung secretions in patients with chronic bronchitis: effect of terbutaline and ipratopium bromide aerosols. Eur J Respir Dis 1980;61:245-53.

4 Lippmann M, Albert RE. The effect of particle size on the regional deposition of inhaled aerosols in the human respiratory tract. Am Ind Hyg Ass J 1969;30:257-75.

5 Agnew JE, Pavia D, Clarke SW. Airways penetration of inhaled radioaerosol: an index to small airways function? Eur J Respir Dis 1981;62:239-55.

6 Bohning DE, Atkins HL, Cohn SH. Long-term particle clearance in man: normal and impaired. Ann Occ Hyg 1982;26:259-71.

7 Agnew JE, Bateman JRM, Pavia D, Clarke SW. A model for assessing bronchial mucus transport. $J$ Nucl Med 1984;25:170-6.

8 Armitage P. Statistical methods in medical research. Oxford: Blackwell Scientific Publications, 1971.

9 Asmundsson T, Kilburn KH. Mucociliary clearance rates at various levels in dog lungs. Am Rev Respir Dis 1970;102:388-97.

10 Iravani J, Van As A. Mucus transport in the tracheobronchial tree of normal and bronchitic rats. $J$ Pathol 1972;106:81-93.

11 Sadé J, Eliezer N, Silberberg A, Nevo AC. The role of mucus in transport by cilia. Am Rev Respir Dis 1970;102:48-52.

12 King M, Gilboa A, Meyer FA, Silberberg A. On the transport of mucus and its rheological simulants in ciliated systems. Am Rev Respir Dis 1974;110:740-5.

13 Lopez-Vidriero MT. Airway mucus: production and composition Chest 1981;80:799-804.

14 Silberberg A. Biorheological matching: mucociliary interaction and epithelial clearance. Biorheology 1983; 20:215-22.

15 Cutz E, Conen PE. Ultrastructure and cytochemistry of Clara cells. Am J Pathol 1971;62:127-42.

16 Widdicombe JG, Pack RJ. The Clara cell. Eur J Respir Dis 1982;63:202-20.
17 Van As A. Pulmonary airway clearance mechanisms: a reappraisal. Am Rev Respir Dis 1977;115:721-6.

18 Rensch H, Von Seefeld H, Gebhardt KF, Renzow D, Sell P-J. Stop and go particle transport in the peripheral airways? A model study. Respiration 1983;44:346-50.

19 Ebert RV, Hanks PB. Mucus secretion by the epithelium of the bronchioles of cigarette smokers. $\mathrm{Br} J$ Dis Chest 1981;75:277-82.

20 Ebert RV, Terracio MJ. The bronchiolar epithelium in cigarette smokers: observations with the scanning electron microscope. Am Rev Respir Dis 1975;111:4-11.

21 Cosio MG, Hale KA, Niewoehner DE. Morphologic and morphometric effects of prolonged cigarette smoking on the small airways. Am Rev Respir Dis 1980; 122:265-71

22 Wright JL, Lawson LM, Pare PD, Wiggs J, Kennedy S, Hogg JC. Morphology of peripheral airways in current smokers and ex-smokers. Am Rev Respir Dis 1983; 127:474-7.

23 Lumsden AB, McLean A, Lamb D. Goblet and Clara cells of human distal airways: evidence for smoking induced changes in their numbers. Thorax 1984;39:844-9.

24 Gerrity TR, Lee PS, Hass FJ, Marinelli A, Werner P, Lourenço RV. Calculated deposition of inhaled particles in the airway generations of normal subjects. $J$ Appl Physiol 1979;47:867-73.

25 Agnew JE. Physical properties and mechanisms of deposition of aerosols. In: Clarke SW, Pavia D, eds. Aerosols and the lung: clinical and experimental aspects. London: Butterworths, 1984:49-70.

26 Petty TL, Silvers GW, Stanford RE. Small airway dimension and size distribution in human lungs with an increased closing capacity. Am Rev Respir Dis 1982; 125:535-9.

27 Lourenço RV, Klimek MF, Borowski CJ. Deposition and clearance of $2 \mu$ particles in the tracheobronchial tree of normal subjects-smokers and non-smokers. $J$ Clin Invest 1971;50:1411-20.

28 Reynolds HY, Newball HH. Analysis of proteins and respiratory cells obtained from human lungs by bronchial lavage. $J$ Lab Clin Med 1974;84:559-73.

29 Low RB, Davis GS, Giancola MS. Biochemical analyses of bronchoalveolar lavage fluids of healthy human volunteer smokers and non-smokers. Am Rev Respir Dis 1978;118:863-75.

30 Jones JG, Minty BD, Lawler P, Hulands G, Crawley $\mathrm{JCW}$, Veall $\mathrm{N}$. Increased alveolar epithelial permeability in cigarette smokers. Lancet 1980;i:66-8.

31 Macklem PT, Proctor DF, Hogg JC. The stability of peripheral airways. Respir Physiol 1970;8:191-203.

32 Hills BA, Barrow RE. An "engine" phenomenon displayed by monolayers of a pulmonary surfactant cycled to a steady state. Phys Med Biol 1984;29:1399-408.

33 Hoidal JR, Niewoehner DE. Lung phagocyte recruitment and metabolic alterations induced by cigarette smoke in humans and in hamsters. Am Rev Respir Dis 1982;126:548-52.

34 Hinds W, First MW, Huber GL, Shea JW. A method for measuring respiratory deposition of cigarette smoke during smoking. Am Ind Hyg Assoc $J$ 1983;44:113-8.

35 Fuchs NA. The mechanics of aerosols. Oxford: Pergamon, 1964.

36 Davies CN, Heyder J, Subba Ramu MC. Breathing of half-micron aerosols. I. Experimental. J Appl Physiol 1972;32:591-600. 
37 Camner P. Clearance of particles from the human tracheobronchial tree. Clin Sci 1980;59:79-84.

38 Isawa T, Teshina T, Hirano T, Ebina A, Konno K. Mucociliary clearance mechanism in smoking and nonsmoking normal subjects. J Nucl Med 1984;25:352-9.

39 Pavia D. Lung mucociliary clearance. In: Clarke SW, Pavia D, eds. Aerosols and the lung: clinical and experimental aspects. London: Butterworths, 1984:127-55.

40 Foster WM, Langenback EG, Bergofsky EH. Disasso- ciation in the mucociliary function of central and peripheral airways of asymptomatic smokers. Am Rev Respir Dis 1985;132:633-9.

41 Sutton PP. Chest physiotherapy and cough. In: Clarke SW, Pavia D, eds. Aerosols and the lung: clinical and experimental aspects. London: Butterworths, 1984:156-69.

42 Puchelle E, Zahm JM, Girard F, et al. Mucociliary transport in vivo and in vitro. Relations to sputum properties in chronic bronchitis. Eur J Respir Dis 1980;61:254-64. 